Acta Theriologica, Suppl. 3: 65-74, 1995.

PL ISSN 0001-7051

\title{
Non-metric traits: remarks on sex dependence, age dependence, and on intercorrelations among characters
}

\author{
Janusz MARKOWSKI
}

\begin{abstract}
Markowski J. 1995. Non-metric traits: remarks on sex dependence, age dependence, and on intercorrelations among characters. IIn: Ecological genetics in mammals II. G. B. Hartl and J. Markowski, eds]. Acta Theriologica, Suppl. 3: 65-74.

Interdependence among non-metric traits as well as their correlation with sex, age, and body size usually cause methodological problems in phenetic investigations. Based on data on four mammalian species (Microtus oeconomus, M. limnophilus, Lepus europaeus, Capreolus capreolus) studied by the author, and on data from the literature these problems were analyzed. Both the number and the coefficients of intercorrelations among traits were found to depend on sample sizes of individuals examined. They were larger in populations with progressive and faster body growth. The number of traits related to sex increased significantly with sex dimorphism across mammalian species. Age dependence of traits did not show a regular pattern within and among species. These results are discussed as to their implications for estimating morphological differentiation within and among populations.
\end{abstract}

Department of Ecology and Vertebrate Zoology, University of Łódź, Banacha str. 12/16, 90-237 Łódź, Poland

Key words: Microtus, Lepus, Capreolus, non-metric traits, effect of sex and age

\section{Introduction}

Non-metric traits of the skeleton have been widely used in studies on mammals and humans for analyzing diversity within and among populations and species (eg Wood-Jones 1933-1934, Brothwell 1958, Berry 1963, Berry and Berry 1967, Markowski and Sikorski 1987, Bauchau 1988). Numerous genetical studies on minor variants of the skeleton have been performed by Grüneberg and his co-workers in inbred strains of mice (Grüneberg 1950, 1952, 1955), who showed that these traits are determined by polygenes. The latter produce a continuous variation as to the expression of a non-metric trait, but the ultimate realization of this variation is dependent on whether or not the respective genetic alterations do exceed a particular physiological threshold (Falconer 1960). Generally, results from mouse genetics should not be extrapolated to other mammals or to man without some reservations. However, family and population studies on non-metric variability in humans do support the argument that the variants are inherited in a similar way in mice and men (Berry 1968). The sixties witnessed the formulation 
of the main practical and statistical principles for analyzing non-metric variation, and the following advantages of using this technique for assessing variation at the population level were derived: (1) They can be rapidly and easily scored on mammalian skeletons commonly accessible in museum collections. (2) Non-metric variation is not affected by sex and age of the specimens. (3) Non-metric variants are usually not intercorrelated among traits.

The acceptance of the second and especially of the third argument led to the statement that "computation of multivariate statistics is much simpler than it is the case for metrical characaters and there are grounds for beliving that estimates of divergence between samples based on differences in non-metrical variant incidence more accurately reflect genetical differences than statistics calculated from metrical data" (Berry 1968). Based this assumption numerous researchers ingored the problem of intercorrelations among traits or considered statistical significance of such observations to be random (eg Truslowe 1961, Berry and Berry 1967, Corruccini et al. 1974). Only in the late 1960s and in the 1970s the presence of essential interdepenedence between non-metric traits as well as sex and age dependence of non-metric variants were pointed out in the course of studies on mammalian and primeval human populations (eg Herzog 1968, Sjøvold 1977). Since that time the value of non-metric traits for population studies has been questioned and, based on data from a limited number of species and populations, problems of intercorrelations, sex dependence and age dependence have been tackled by various authors (eg Finnegan 1972 after Sjøvold 1977, Sjøvold 1977, Cheverud and Buikstra 1982, Dodo and Ishida 1987).

To arrive at more general conclusions about the importance of these phenomena the purpose of the present study is twofold: to examine intercorrelations among non-metric traits in relation to sample sizes of individuals and populations, and to investigate sex and age dependence of non-metric traits within and among populations of various species. Regarding the latter aspect, the relationship between sex dependence of traits and the extent of sexual dimorphism of a species will be emphasized.

\section{Material and methods}

A total of 6520 skulls of four mammalian species were studied during the last decade in the course of three diffrent research projects granted to the author (for detalis see Table 1). For two species of voles [Microtu oeconomus (Pallas, 1776), M. limnophilus (Büchner, 1889)] and for the roe deer Capreolus capreolus (Linnaeus, 1758), data on sex was taken from the records of previous studies (Markowski 1980, 1992, Markowski and Markowska 1988). In the brown hare Lepus europaeus (Pallas, 1778), sex determination was preformed by inspection of the internal reproductive organs. Age of voles was determined using dry eye lens weight, obliteration of sutures, and development of bone crests following the description by Markowski (1980). Age in roe deer specimens was determined on the basis of the teeth wear (Pielowski 1970). Brown hares were aged exclusively using dry eye lens weight $(<270 \mathrm{mg}$ - juveniles, $>270 \mathrm{mg}-$ adults $)$. 
Table 1. Specimens examined in the present study. $n(\mathrm{I})$ - number of individuals studied, $n(\mathrm{P})$ - number of populations studied.

\begin{tabular}{lccc}
\hline Species & $n(\mathrm{I})$ & $n(\mathrm{P})$ & \multicolumn{1}{c}{ Source } \\
\hline Microtus oeconomus & 3950 & 121 & $\begin{array}{l}\text { Collections of 18 institutions } \\
\text { (Markowski 1992) }\end{array}$ \\
Microtus oeconomus & 2138 & 1 & $\begin{array}{l}\text { Northern Poland } \\
\text { (Markowski 1978, 1980, } \\
\text { J. Markowski and Z. Pucek, in } \\
\text { prep.) }\end{array}$ \\
$\begin{array}{l}\text { Lepus europaeus } \\
\text { Capreolus capreolus }\end{array}$ & 279 & 7 & $\begin{array}{l}\text { (J. Markowski, unpubl.) } \\
\text { (Markowski and Markowska 1988) }\end{array}$
\end{tabular}

Different sets of non-metric traits were used in the respective species. These were described and illustrated previously by Markowski and Markowska (1988) and Markowski (1992). To minimize inter-observer differences in scoring, all the data were collected by myself.

In cases were otherwise bilateral traits occurred only unilaterally the respective specimen was excluded from the analysis. Frequencies of traits within samples were calculated taking into account sex, age and geographic origin of specimens.

Non-metric variants were examined for intercorrelation among traits, for sex dependence and for age dependence using the Pearson correlation coefficient. Associations between non-metric variants and body size (in terms of body mass) were tested by the point-biserial correlation coefficient of Pearson (Sjøvold 1977). For evaluating the relationship between the extent of sexual dimorphism and the frequency of sex dependent non-metric variants the Spearaman rank correlation coefficient was used.

\section{Results}

Frequencies of correlations among non-metric traits emerging from the data of the present study along with the results of some previous investigations by other authors are given in Table 2. In a number of species the frequency of significant correlations among traits proved to be higher (ie 0.05) than to be expected by chance. However, the maximum correlation coefficients obtained are, on the whole, rather low (Table 2). A detailed analysis of levels of intertrait correlations in relation to sample sizes was carried out using numerous series of $M$. oeconomus skulls. Separately for males and females, correlation coefficients were calculated for random samples with increasing numbers of specimens $(n=25-800)$. Above a sample size of 200 individuals the frequency of statistically significant intercorrelations was always higher than to be expected by chance and still increased with sample size. By contrast, the maximum correlation coefficient noted in particular samples decreased with sample size in both sexes, especially within the range of 25-100 specimens analyzed (Table 3).

Frequencies of significant correlations of non-metric traits with sex, age, and body mass, along with data presented by other authors are given in Table 4 . The 
Table 2. Frequency (FR) and maximum value (MV) of significant Pearson correlation corefficients among non-metric traits. (** mean that the frequency is significantly greater than $5 \%$ at $p<0.01$ ). $n(\mathrm{I})$ - sample size of individuals, $n(\mathrm{~T})$ - number of traits studied. $\mathrm{F}-$ females, $\mathrm{M}$ - males.

\begin{tabular}{|c|c|c|c|c|c|c|}
\hline Species & Sex & $n(\mathrm{I})$ & $n(\mathrm{~T})$ & FR & MV & Source \\
\hline Microtus oeconomus & $\begin{array}{l}\mathrm{F} \\
\mathrm{M} \\
\mathrm{F}+\mathrm{M}\end{array}$ & $\begin{array}{r}998 \\
1140 \\
2138\end{array}$ & $\begin{array}{l}27 \\
27 \\
27\end{array}$ & $\begin{array}{l}14.8^{* * *} \\
16.5^{* * *} \\
22.8^{* *}\end{array}$ & $\begin{array}{l}0.21 \\
0.19 \\
0.24\end{array}$ & J. Markowski and Z. Pucek, in prep. \\
\hline Microtus oeconomus & $\begin{array}{l}F \\
M \\
F+M\end{array}$ & $\begin{array}{l}1930 \\
1604 \\
3679\end{array}$ & $\begin{array}{l}31 \\
31 \\
31\end{array}$ & $\begin{array}{l}13.1^{* * *} \\
10.1^{* *} \\
16.1^{* *}\end{array}$ & $\begin{array}{l}0.16 \\
0.12 \\
0.19\end{array}$ & Markowski 1992 \\
\hline Microtus limnophilus & $\begin{array}{l}\mathrm{F} \\
\mathrm{M} \\
\mathrm{F}+\mathrm{M}\end{array}$ & $\begin{array}{l}20 \\
17 \\
39\end{array}$ & $\begin{array}{l}23 \\
23 \\
23\end{array}$ & $\begin{array}{l}3.2 \\
3.6 \\
5.1\end{array}$ & $\begin{array}{l}0.48 \\
0.68 \\
0.50\end{array}$ & Markowski 1992 \\
\hline Mus musculus & $\mathrm{F}+\mathrm{M}$ & 851 & 36 & 1.1 & 0.29 & Berry and Jakobson 1975 \\
\hline Apodemus agrarius & $\mathrm{F}+\mathrm{M}$ & 254 & 26 & 8.9 & & Sikorski 1982 \\
\hline Lepus europaeus & $\begin{array}{l}\mathrm{F} \\
\mathrm{M} \\
\mathrm{F}+\mathrm{M}\end{array}$ & 295 & $\begin{array}{l}47 \\
47 \\
47\end{array}$ & $\begin{array}{l}6.9 \\
7.5 \\
9.2^{* *}\end{array}$ & $\begin{array}{l}0.30 \\
0.32 \\
0.27\end{array}$ & J. Markowski, unpubl. \\
\hline Vulpes vulpes & $\begin{array}{l}\mathrm{F} \\
\mathrm{M} \\
\mathrm{F}+\mathrm{M}\end{array}$ & $\begin{array}{l}1068 \\
1284 \\
2352\end{array}$ & $\begin{array}{l}19 \\
19 \\
19\end{array}$ & $\begin{array}{r}5.8^{* * *} \\
5.8^{* * *} \\
15.8^{* * *}\end{array}$ & $\begin{array}{l}0.12 \\
0.08 \\
0.11\end{array}$ & Sjøvold 1977 \\
\hline Lynx $\operatorname{lyn} x$ & $\mathrm{~F}+\mathrm{M}$ & 100 & 53 & $7.8^{* *}$ & 0.36 & Wiig and Andersen 1988 \\
\hline Capreolus capreolus & $\mathrm{F}+\mathrm{M}$ & 369 & 78 & $17.5^{* *}$ & 0.25 & Markowski and Markowska 1988 \\
\hline
\end{tabular}

Table 3. Frequency (FR) and maximum value (MV) of significant Pearson correlation coefficients among non-metric traits in relation to sample size $[n(\mathrm{I})]$ in randomly chosen samples of $M$. oeconomus. *, ** mean that the frequency is significantly greater than $5 \%$ at $p<0.05$ and $p<0.01$, respectively.

\begin{tabular}{rlllll}
\hline & \multicolumn{2}{c}{ Females } & & \multicolumn{2}{c}{ Males } \\
\cline { 2 - 3 } \cline { 5 - 6 }$n(\mathrm{I})$ & FR & MV & & FR & MV \\
\hline 25 & 3.16 & 0.72 & & 2.37 & 0.66 \\
50 & 3.55 & 0.69 & & 2.63 & 0.55 \\
100 & 3.16 & 0.39 & & 3.55 & 0.41 \\
200 & 5.53 & 0.18 & & 3.95 & 0.24 \\
400 & $6.32^{* *}$ & 0.20 & & $5.94^{*}$ & 0.15 \\
800 & $7.90^{* *}$ & 0.14 & & $7.11^{* *}$ & 0.18 \\
\hline
\end{tabular}

percentage of traits related to sex in the present study was very low and varied between 0 and $4 \%$. In the voles and the brown hare this result was largely the 
Table 4. Frequency (FR) of significant Pearson correlation coefficients between non-metric traits and sex $(\mathrm{S})$, age $(\mathrm{A})$, and body mass $(\mathrm{B})$ in various mammalian species. $n(\mathrm{~T})$ - number of traits examined. $\mathrm{F}$ - females, $\mathrm{M}$ - males.

\begin{tabular}{|c|c|c|c|c|c|}
\hline Species & $n(\mathrm{~T})$ & $\mathrm{FR}(\mathrm{S})$ & FR(A) & $\mathrm{FR}(\mathrm{B})$ & Source \\
\hline Microtus oeconomus & 27 & 0 & 11.0 & 11.0 & J. Markowski and Z. Pucek, in prep. \\
\hline Microtus oeconomus & 31 & 3.2 & $\begin{array}{r}\mathrm{F} 0 \\
\mathrm{M} 0 \\
\mathrm{~F}, \mathrm{M} 0\end{array}$ & $\begin{array}{r}\text { F } 9.7 \\
\text { M } 3.2 \\
\text { F, M } 6.4\end{array}$ & Markowski 1992 \\
\hline Microtus limnophilus & 23 & 0 & $\mathrm{~F}, \mathrm{M} 0$ & $\mathrm{~F}, \mathrm{M} 0$ & Markowski 1992 \\
\hline Mus musculus & 36 & 2.8 & - & - & Berry and Jakobsen 1975 \\
\hline Apodemus agrarius & 26 & $\begin{array}{l}7.7- \\
11.5\end{array}$ & F, M 19.2 & - & Sikorski 1982 \\
\hline Lepus europaeus & 47 & 4.3 & $\begin{array}{c}\text { F } 6.4 \\
\text { M } 4.3\end{array}$ & $\begin{array}{l}\text { F } 2.1 \\
\text { M } 0\end{array}$ & J. Markowski, unpubl. \\
\hline Vulpes vulpes & 19 & $0-28.6$ & $\begin{array}{r}\text { F } 0-10.5 \\
\text { M } 5.2-21.0\end{array}$ & $\begin{array}{l}\text { F } 36.8 \\
\text { M } 42.1\end{array}$ & Sjøvold 1977 \\
\hline Lynx lynx & 53 & 7.5 & F, M 15.1 & - & Wiig and Andersen 1988 \\
\hline Cystophora cristata & 18 & 27.8 & - & - & Wiig and Lie 1984 \\
\hline Capreolus capreolus & 78 & 3.6 & $\begin{array}{r}\text { F } 3.6 \\
\text { M } 5.0\end{array}$ & $\begin{array}{r}\text { F } 6.4 \\
\text { M } 11.7\end{array}$ & Markowski and Markowska 1988 \\
\hline
\end{tabular}

same in both sexes, but in the roe deer the males showed a considerably higher number of sex-correlated traits than the females (Table 4). Condylobasal length for the species studied (Markowski 1980, Wiig and Lie 1984, Wiig and Andersen 1986, and own unpublished data on Capreolus capreolus and Lepus europaeus) was used for calculating the index of sexual dimorphism according to Storer (1966). This index is the quotient obtained by dividing the mean difference between condylobasal lengths of mature males and females by the sum of the mean values of both sexes. Storer's index was significantly positively correlated with the frequency of traits related to $\operatorname{sex}\left(r_{\mathrm{S}}=0.79, n=8, p<0.02\right)$. Non-metric traits displayed the highest frequency of correlations with age $(0-0.11)$ and with body mass $(0-0.13$, Table 4$)$.

\section{Discussion}

Only in the first studies on non-metric traits the number of significant associations between traits has been low enough to be due to chance (Truslowe 1961, Berry and Berry 1967, Corruccini 1974, Berry and Jakobsen 1975, Kellock and Parsons 1970). Later a much higher number of significant associations among traits has been reported in several mammalian species (Sjøvold 1977, Sikorski 
Table 5. Frequency (FR) of significant Pearson correlation coefficients among non-metric traits in relation to geographical latitude for $M$. oeconomus samples of similar size $[n(\mathrm{I})]$.

\begin{tabular}{lrl}
\hline Location & $n(\mathrm{I})$ & FR \\
\hline Kisbalaton $\left(46^{\circ} 40^{\prime} \mathrm{N}, 17^{\circ} 20^{\prime} \mathrm{E}\right)$ & 100 & 2.77 \\
Augustowska Forest $\left(53^{\circ} 22^{\prime} \mathrm{N}, 23^{\circ} 22^{\prime} \mathrm{E}\right)$ & 100 & 4.33 \\
Hardangervidda $\left(60^{\circ} 32^{\prime} \mathrm{N}, 7^{\circ} 30^{\prime} \mathrm{E}\right)$ & 100 & 5.02 \\
St. Lawrence $\left(63^{\circ} 10^{\prime} \mathrm{N}, 170^{\circ} 30^{\circ} \mathrm{W}\right)$ & 116 & 5.53 \\
Ogoturuk Creek $\left(68^{\circ} 04^{\prime} \mathrm{N}, 165^{\circ} 58^{\prime} \mathrm{W}\right)$ & 97 & 7.11 \\
Pitmegea $\left(68^{\circ} 55^{\prime} \mathrm{N}, 164^{\circ} 36^{\prime} \mathrm{W}\right)$ & 86 & 5.13 \\
Kilpisjärvi $\left(69^{\circ} 03^{\prime} \mathrm{N}, 20^{\circ} 49^{\prime} \mathrm{W}\right)$ & 101 & 5.13 \\
\hline
\end{tabular}

1982, Wiig and Andersen 1988, Markowski and Markowska 1988) as well as in human populations (Herzog 1968, Benfer 1970, Corruccini 1974). What are the causes of the increased number of correlations among traits? Sjøvold (1977), who has paid much attention to the problem of interdependence among traits in the red fox Vulpes vulpes, stated that significant correlations among traits may be due to genetic or environmental influences, yet the increase of such correlations in pooled samples should be mostly a statistical effect. Sjøvold's hypothesis is corroborated by the data presented in Table 3. Since non-metric traits have a pleiotropic genetic basis (Berry and Berry 1967) intercorrelations among traits may be due to a variety of genetic and environmental influences. Microtus oeconomus with its circumpolar distribution may be a good model to verify the role of environmental influences on the number of intercorrelations among traits. To avoid sample size effects on the number of intercorrelations observed, only populations with more than 80 specimens sampled were considered. In each of three populations with sample sizes higher than 150, a total of 100 induviduals were randomly chosen. The reults revealed a higher percentage of traits to be correlated in the northernmost population (Table 5). Altogether, the geographic location (in terms of latitude) proved to be strongly positively correlated with the percentage of correlated traits observed $\left(r_{\mathrm{S}}=0.82, n=7, p<0.01\right)$, which may be explained by a progressive and more rapid growth of the skull during postnatal devleopment (see below).

A number of other authors have stressed the occurrence of significant correlations among traits belonging to the same topographic and topological group on the skull (Rössing 1982, Molto 1985, Česnys 1988). For example, in analyzing pairwise intercorrelations in 44 cranial non-metric traits on human skulls, Česnys (1988) generally detected both a relatively low frequency of correlations (7.5\%), and low correlation coefficients $(0.08-0.14)$. However, traits belonging to the same anatomical type (eg sutures, foramina, fenestrae) displayed correlation coefficients up to 0.30 . In contrast, Cooprider et al. (1980) attributed at least half of the significant correlations among traits to physiological processes related to ossi- 
fication in general. Also cranial deformation is known to have an influence on correlations among metric variables in humans, but its effects on the expression of non-metric traits has not been worked out in detail so far (see Konigsberg et al. 1993). In experiments on rats, Pucciarelli (1974) was able to demonstrate that deformation of the skull can increase the frequency of wormian bones. However, since in $M$. oeconomus also the frequency of wormian bones increased gradually from southern to northern populations (Markowski 1992), their occurrence may be due to adaptation as well. Similar results were obtained in Lynx rufus (Manville 1959) and in Dyromys nitedula (Pucek 1962).

The information avialable in the literature on relationships between non-metric traits and sex, age, and body size is controversial. The investigation of a considerable number of skeletons of Mus musculus, both from wild populations and laboratory strains revealed a correlation with sex in some non-metric traits (Berry and Jakobson 1975). The same was found by Sjøvold (1977), Sikorski (1982), Wiig and Lie (1984), Wiig and Andersen (1988) in some further mammalian species (Table 4). By contrast, Wiig and Lie (1979) did not find any correlation of non-metric traits with sex in the American mink Mustela vison, a species introduced to Norway at the beginning of the 1970 s. Similar results were obtained by J. Markowski and Z. Pucek (in prep.) for a population of the root vole from Augustowska Forest (north-eastern Poland).

The percentage of traits related to sex in the mammalian species investigated varied within a broad range $(0-29 \%)$. The same was true for adjacent populations of the same species, (eg in Apodemus agrarius - Sikorski 1982, and in V. vulpes - Sjøvold 1977) and for races of man. Corruccini (1974) found $31 \%$ and $15 \%$ of the traits correlated with sex in whites and blacks, respectively. Similarly high values were recorded for populations in Lithuania (Česnys 1982) and Hungary (Finnegan and Marčsik 1979), while estimates were lower for North Americans (4\%, Ossenberg 1976), Australians (8\%, Milne et al. 1983), and Japanese (9.7\%, Mouri 1976). These results made part of anthropologiste believe that non-metric traits are generally related to sex (Perizonius 1979, Milne et al. 1983). In further investiagtions certain traits have been in fact considered typical for males and females, respectively (see Dodo 1974, Mouri 1976).

To avoid mistakes in estimating morphological distances among human populations, Finnegan (1972) after Sjøvold (1977) suggested to use similar numbers of males and females, while Gaherty (1974) recommended a separate treatment of traits related and not related to sex. Cheverud and Buikstra (1982) were rigorous in excluding sex-related traits totally from population analyses, but Ossenberg (1976), and Dodo and Ishida (1987) stated that such traits do not lead to seriously biased MMDs, and measurements of both sexes may be combined. Irrespective of the concept adopted for calculating MMDs, the presence of sex-related traits remains to be explained. Osseneberg (1970) emphasized the ethiological subdivision of traits into hypo- and hyperostotic. According to her, hypoostotic traits occur more frequently in females and hyperostotic traits mor frequently in males. 
However, further investigations on human populations revealed the presence of male and female traits, which were not always congruent with the classification of Ossenberg (Dodo 1974, Mouri 1976). Altogether, due to a comparatively low number of traits correlated with sex and the difficulty of their uneqivocal assignment to one of the two ethiological groups Ossenberg's hypothesis could not be verified. Another explanation was presented by Sjøvold (1977). In his opinion the presence of traits related to sex is associated with sexual dimorphism in terms of body size. This hypothes is strongly supported by the results of the present study and those of other investigations (Sjøvold 1977, Wiig and Andersen 1988).

The percentage of traits related to age and body size in the mammalian species studied so far ranges from $3 \%$ in $M$. oeconomus to $42 \%$ in V. vulpes (see Table 4). Regarding age dependence of traits, studies on human populations yielded a similar result (4\% - Corruccini 1974, 2.3\% - Česnys and Konductorova 1982, 50\% - Česnys 1988, 62\% - Piontek 1985). Age dependence of traits can be explained by changes in the skeletal structure during postnatal development, which are strongly influenced by both pleiotropic genetic effects and environmental factors (see eg Berry 1968, Pucciarelli 1974).

Many foramina (for nerves and blood vessels) appear together with a progressive development of the faciocranium, especially in nasal, maxillary or dental bones. This is supported by the results of Wiig and Andersen (1988), who found altogether $13 \%$ of the traits analyzed in Lynx lynx correlated with age, but this value decreased to $5.6 \%$ when only individuals older than 18 months were considered. Similar results were obtained in our study on populations of Capreolus capreolus (Markowski and Markowska 1988) where 3.6\% of the traits were age dependent in the total material, but none of these correlations were found in animals older than two years. Based on material from human populations Ossenberg (1970) and Rössing (1982) suggested progressive development to be characteristic for hyperostotic traits and regressive development for hypoostotic ones. But in studies on mammals contradictory results were obtained. In C. capreolus and $M$. oeconomus age dependent traits all belonged to the hyperostotic group, while in L. lynx foramina of the frontal and orbital region (included to the hyperostotic group) proved to be either positively or negatively correlated with age (Wiig and Andersen 1988).

\section{References}

Bauchau V. 1988. Non-metrical variation in wild mammals: a bibliography. Mammal Review 18: $195-200$

Benfer R. A. 1970. Associations among cranial traits. American Journal of Physical Anthropology 32: 463-464.

Berry A. C. and Berry R. J. 1967. Epigenetic varition in the human cranium. Journal of Anatomy 101: 361-379.

Berry R. J. 1963. Epigenetic polymorpohism in wild population of Mus musculus. Genetical Research 4: 193-220. 
Berry R. J. 1968. The biology of non-metrical variation in mice and men. [In: The skeletal biology of earlier human populations. D. R. Brothwell, ed]. Pergamon Press, New York: 103-133.

Berry R. J. and Jakobson M. E. 1975. Ecological genetics of an island population of the house mouse (Mus musculus). Journal of Zoology, London 175: 523-540.

Brothwell D. R. 1958. The use of non-metrical characters of the skull in differentiating populations. Deutsche Gesellschaft für Antropologie 6: 103-109.

Cheverud J. and Buikstra J. 1982. Quantitative genetics of skeletal non-metric traits in the rhesus macaques on Cayo Santiago. III. Realtive heritability of skeletal nonmetric and metric traits. American Journal of Physical Anthropology 59: 151-155.

Česnys G. 1982. Relation of non-metric cranial traits to sex, and age in the 1st-2nd millenium A. D. Lithuanian craniological materials. Humanbiologia Budapestensis 10: 19-24.

Česnys G. 1988. [Correlation of discrete traits in human skulls on an example of medieval craniological series from Vilnyus]. Fentika prirodnykh populayacii. Moskva: 201-208. [In Russian]

Česnys G. and Konductorova T. S. 1982. Nonmetric features of the skull in poeple of Chernyakhovskaya culture. Voprosy antropologii 70: 62-76.

Cooprider K. B., Rubinson R. M. and Finnegan M. 1980. Racial classification based on non-metric skeletal traits. Homo 31: 1-21.

Corruccini R. 1974. An examination of the meaning of cranial discrete traits for human skeletal biological studies. American Journal of Physical Anthropology 40: 425-446.

Dodo Y. 1974. Non-metrical cranial traits in the Hokkaido Ainu and the northern Japanese of recent times. Journal of the Anthropology Society of Nippon 82: 31-51.

Dodo Y. and Ishida H. 1987. Incidence of nonmetric cranial variants in several populations samples from east Asia and north America. Journal of the Anthropology Society of Nippon 95: 161-177.

Falconer D. S. 1960. An introduction to quantitative genetics. Oliver and Boyd. Edinburgh-London: $1-321$.

Finnegan M. and Marčsik A. 1979. A non-metric examination of the realtionships between osteological remains from Hungary representing population of avar period. Acta Biologica, Seged 25: 97-118.

Gaherty G. 1974. Discrete traits, cranial measurements and non-biological data in Africa. American Journal of Physical Anthropology 40: 136-142.

Grüneberg H. 1950. Genetical studies on the skeleton of the mouse. I. Minor variation of the vertebral column. Journal of Genetics 50:112-141.

Grüneberg H. 1952. Genetical studies on the skeleton of the mouse. IV. Quasi-continuous variation. Journal of Genetics 51: 95-114.

Grüneberg H. 1955. Genetical studies on the skeleton of the mouse. XV. Relations between major and minor variants. Journal of Genetics 53: 515-535.

Herzog K. P. 1968. Associations between discontinuous cranial traits. American Journal of Physical Antropology 29: 397-403.

Kellock W. L. and Parsons P. A. 1970. Variation of minor non-metrical cranial variants in Australian aborigenes. American Journal of Physical Anthropology 32: 409-421.

Konigsberg L. W., Kohn L. A. P. and Cheverud J. M. 1993. Cranial deformation and nonmetric trait variation. American Journal of Physical Anthropology 90: 35-41.

Manville R. H. 1959. Bregmatic bones in north american lynx. Science 120: 1254.

Markowski J. 1980. Morphometric variability ina population of the root vole. Acta Theriologica 25: $155-211$.

Markowski J. 1992. Non-metric traits in mammalian population studies. Acta Universitatis Lodziensis, Łódź: 1-116. [In Polish]

Markowski J. and Markowska M. 1988. Non-metrical variation in three populations of the roe deer. Acta Theriologica 33: 519-536.

Markowski J. and Sikorski M. D. 1987. The use of non-metric traits in populational studies. Przegląd Zoologiczny 31: 7-23. [In Polish with English summary] 
Milne N., Schmitt L. H. and Freedman L. 1983. Discrete traits variation in western Australian Aboriginal skulls. Journal of Human Evolution 12: 157-168.

Molto J. D. 1985. Simultaneous occurrence of disconinous cranial traits: some theoretical and practical consideration for population studies. Canadian Journal of Anthropology 4: 57-65.

Mouri T. 1976. A study of non-metrical cranial variants of modern Japanese in the Kinki district. Journal of the Anthropology Society of Nippon 84: 191-203.

Osseneberg N. S. 1970. The infuence of artificial cranial deformation on discontiuous morphological traits. American Journal of Physical Anthropology 33: 357-372.

Osseneberg N. S. 1976. Within and between race distance in population studies based on discrete traits of the human skulls. American Journal of Physical Anthropology 45: 701-716.

Perizonius W. R. K. 1979. Non-metrical cranial traits: sex differences and age dependece. Journal of Human Evolution 8: 679-684.

Pielowski Z. 1970. [The roe deer]. PWRiL, Warszawa: 1-220. [In Polish]

Piontek J. 1985. Natural selection and non-metric traits. [In: Evolution and morphogenesis. J. Milikovsky and V. J. A. Novak, eds]. Academia Praha, Praha: 629-634.

Pucciarelli H. M. 1974. The influence of experimental deformation on neurocranial wormian bones in rats. American Journal of Physical Anthropology 41: 29-38.

Pucek Z. 1962. The occurrence of wormian bones (Ossicula wormiana) in some mammals species. Acta Theriologica 6: 33-51.

Rössing F. W. 1982. Discrete des menschliches Skeletts. Ein kritischer Überblick. Homo 33: 100-125.

Sikorski M. D. 1982. Non-metrical divergence of isolated populations of Apodemus agrarius in urban areas. Acta Theriologica 27: 169-180.

Sjøvold T. 1977. Non-metrical divergence between skeletal populations. Ossa 4, suppl. 1: 1-123.

Storer R. W. 1966. Sexual dimotphism and food habitats in three North American accipiters. Auk 83: 423-436.

Truslowe G. M. 1961. Genetical studies on the skeleton of the mouse. XXX. A search for correlation between some minor variants. Genetical Research 2: 431-438.

Wiig $\emptyset$. and Andersen T. 1986. Sexual size dimorphism in the skull of Norwegian lynx. Acta Theriologica 31: 147-155.

Wiig $\emptyset$. and Andresen T. 1988. Non-metrical variation in the skull of Norwegian lynx. Acta Theriologica 33: 3-19.

Wiig $\emptyset$. and Lie R. W. 1979. Metrical and non-metrical skull variations in Norwegian wild mink (Mustela vison Schreber). Zoologica Scripta 8: 297-300.

Wiig $\emptyset$. and Lie R. W. 1984. An analysis of the morphological relationships between the Hodded seals (Cystophora cristata) of Newfoundland, the Danmark strait and Jan Mayen. Journal of Zoology, London 203: 227-240.

Wood-Jones F. 1933-1934. The non-metrical morphological characters of the skull as criteria for racial diagnosis. IV. Journal of Anatomy 68: 96.

Received 7 August 1995, accepted 30 September 1995. 